\title{
Prejudice as moral action in Christian ethical DECISION-MAKING
}

Author:

Stephanus J. Myburgh ${ }^{1}$

\section{Affiliation:}

${ }^{1}$ Methodist Church of southern Africa, Mokopane,

South Africa

\section{Correspondence to:}

Stephanus Myburgh

email:

faanmyb@ananzi.co.za

Postal address:

Methodist Church of southern Africa, PO Box

355, Mokopane 0600,

South Africa

\section{Keywords:}

Christian ethics; ethics of conviction; hermeneutics; objective thinking; prejudices responsibility

\section{Dates:}

Received: 14 Sept. 2009

Accepted: 20 Feb. 2010

Published: 06 May 2010

How to cite this article:

Myburgh, S.J., 2010,

'Prejudice as moral action in Christian ethical decisionmaking', Verbum et Ecclesia 31(1), Art. \#89, 6 pages. DOI: 10.4102/ve.v31i1.89

\section{This article is available} at:

http://www.ve.org.za

Note:

This article is based on research done for a MA (Theol.) dissertation; Undoing Closure: Responsible use of the Bible in Christian Ethical Decision Making, in the department of Dogmatics and Christian Ethics in the faculty of Theology, University of Pretoria.

(c) 2010. The Authors. Licensee: OpenJournals Publishing. This work is licensed under the Creative Commons Attribution License.

\begin{abstract}
Given the many approaches regarding the use of the Bible, the ethical work in biblical interpretation and the work of being concerned with an ethical issue affecting the Christian as a moral agent cannot be separated from one another. This article deals with that affinity between the approach of the interpreter as moral agent, using the Bible in his or her ethical decision-making and aspects that constitute fundamental starting points for him or her in this ethical decision-making, with regard to the liberation of prejudices as that which makes understanding for moral action possible. It is maintained in the article that prejudices that are conformable to the ways in which responsibility should qualify Christian ethics in general make for responsible use of the Bible in Christian ethical decision-making. Prejudices (pre-understanding) that are grounded in an ethics of responsibility allow for the interpreter to adhere to the truth claim of a text, which can only be had from hermeneutical work that promotes prejudices in an intentional and critical way as the link between past text and current interpreter.
\end{abstract}

\section{INTRODUCTION}

Concerning the use of the Bible in the context of Christian ethical decision-making or as a source for moral norms, there are those who maintain 'that the scriptural text can be objectively known, that it has a clear, perspicuous meaning, and that that meaning can be discovered if the text is allowed to interpret itself, without the adulteration of the interpreter's...prejudices' (Montgomery 1995:16). On the other hand, there are those who maintain that the 'text and interpreter are locked together in such a way that a purely objective, 'presuppositionless' understanding of the text is out of the question' (Montgomery 1995:16). It follows that, generally speaking, there are two approaches to hermeneutics. According to Selby (2006:136), 'there are those who ... seek and espouse a methodology with which to begin the interpretative process. Others ... have a more ontologically-orientated bias' where being in support of methodology as starting point leads to objective thinking in biblical interpretation. An 'ontological bias' refers to the notion that, according to Grondin (2003:80) 'all understanding necessarily proceeds [ontologically] from an anticipation of meaning'. This begs the question: where is the location for truth in biblical interpretation when the Bible is being used as a source for moral norms in Christian ethical decision-making?

\section{Two horizons and anticipation of meaning}

The modern understanding of hermeneutics 'begins with the recognition that historical conditioning is two-sided: the modern interpreter, no less than the text, stands in a given historical context and tradition,' according to Thiselton (1980:11). What happens in biblical interpretation is thus a fusion of two horizons; that of the ancient text and the modern interpreter. The horizon of both the biblical author or witness and that of the reader or hearer consists of already granted meanings and intentions' (Thiselton 1980:16), also known as prejudices. This recognition has led to a growing sense that prejudices or pre-understanding play an indispensable part in biblical interpretation, since prejudice 'influences the individual through tradition, and often through his acceptance of certain values, attitudes, or institutions, as authoritative' (Thiselton 1980:305). It is by means of this, the liberation of prejudices as that which make understanding texts from the past possible, that the interpreter is able to adhere to the truth-claim of a text. Finding the meaning of a text is always a productive exercise; it is the fusion of two horizons rather than a mere reconstruction of the past-ness of the text. It is thus necessary to liberate prejudice as a link between past text and current interpreter when the Bible is used in Christian ethical decision-making.

\section{Prejudices as moral actions}

Prejudice, a fundamental human characteristic, makes all understanding possible, including understanding for moral action. It is thus also necessary that prejudice, being that which make understanding for moral action possible, be liberated. If prejudices make understanding possible, the following question arises: which prejudices (pre-understandings) are legitimate? This article, and the research on which it is based, is an endeavour to present a (provisional) answer to this question. Any system of ethics, including Christian ethics, can only take one of two approaches. Either it subscribes to an ethics of conviction or an ethics of responsibility. As fundamental starting points they differ in their value orientation; we are speaking here of 'two kinds of commitment ... and the corresponding value positions' (Weber 1979:88).

The Christian as moral agent, in her or his ethical decision-making and the process of dealing with a specific ethical issue, therefore starts from either an ethics of conviction or an ethics of responsibility. The starting point is therefore already a moral act. In this process of ethical decision-making she or he uses the Bible as a source for moral norms. Employing the Bible in Christian ethical decisionmaking involves engaging in a moral act (the ethics of biblical interpretation). This link, between the moral agent starting from either an ethic of responsibility or an ethic of conviction and the use of the Bible as a moral act, can be had in terms of prejudice as that which makes understanding for moral action possible. 
We can therefore engage in constructing ${ }^{1}$ prejudices, which will lead to acts of interpretation that are responsible in Christian ethical decision-making in a number of ways. Before attempting to construct such prejudices we need to enquire, for the sake of clarity and comparison, into that which is being opposed and an ethic of responsibility.

\section{ETHICS OF CONVICTION AND ETHICS OF RESPONSIBILITY}

\section{Conviction or responsibility}

Here we can draw on the work of Max Weber, who first made a distinction between an ethics of responsibility and an ethics of conviction. This distinction is also referred to by D.E. de Villiers in his work on ethics. ${ }^{2}$ Any ethics, including Christian ethics, can take only one of two approaches: it either follows an ethics of principled conviction or it follows an ethics of responsibility. An ethics of conviction seeks only to strive to 'keep the flame of one's convictions burning, which can only be done regardless of the consequences of one's moral actions and entails blaming any unwanted outcomes on God or some other force. In the framework of ethics of conviction, the different value spheres in which ethical decision-making happens are not considered, and it is thus not in favour of dialogue with other value systems. There is a disregard for the complicated way in which ethical decision-making takes place. In other words, it ignores the hierarchical and pluralistic nature, or the reality of the context(s) in which ethical decision-making takes place. An ethics of responsibility, however, takes all of those aspects in to consideration, as well as the chances of success within a plurality of values, which are often in conflict with one another. In an ethics of conviction, principles are used in a prescriptive manner, whereas in an ethics of responsibility principles are used in a formative or reflexive manner.

For instance, in working out the relation between politics and Christianity, an ethics of conviction would argue for the Christianisation of society and the moral values of the Bible as the only and final determinants for value formation and action in all social spheres. This, however, can only be achieved by an authoritarian kind of enforcement and fuelled by a disregard for the freedom of conscience of others. It thus implies a disregard for the functional and cultural values that may be operating in any given context. It seeks to apply its biblically inspired moral convictions in an absolute way without taking into account the nature of the different value spheres and the particular roleresponsibility in each. As such it regards its own 'interpretation of the moral message of the Bible as the sole and final measure of political policies and actions' (De Villiers 2005:526).

An ethics of responsibility, on the other hand, will promote dialogue between different value systems in order to accommodate them all optimally. It will thus not only consider moral values based on the Bible, but also take note of the functional and other values operating in different contexts. Any system of ethics is a complicated matter in which a person or group of persons have to take responsibility for analysing the concrete situation thoroughly and deliberating the possible consequences of different options for action and also for weighing up the different value systems that are in play before making a decision on the right course of action.

In an ethics of responsibility, by taking into account the different value systems that are in operation in any given situation, the priority of moral and religious values is never taken to be an absolute one. It is not the case that 'moral values always completely replace functional values that seem to be in

\section{Die 'daarstelling' van...}

2.'Special attention should, in my opinion,be given to Max Weber's original distinction between an ethics of conviction and an ethics of responsibility...' (De Villiers 2007a:107). tension with it' (De Villiers 2005:527). It is rather the case that 'the role of moral and religious values over against other values is primarily a limiting one: to prevent them from claiming validity outside their sphere of competence' (De Villiers 2005:528). Moral values can also be used to speak against the 'distorted versions' of other value systems when they become so enmeshed within their own sphere of influence, as for instance when excess use of force is used in order to uphold the a law. Although an ethics of conviction is not without responsibility and an ethics of responsibility is not without convictions, ethical decision-making uses either the one or the other as departure point.

\section{Biblical interpretation and objective thinking}

Smith (1994:292) says, with regard to using the Bible or understanding texts from the past, that the rhetoric of objectivism - the invocation of self-evident truth and objective fact, intrinsic value and absolute right, of that which is universal, total, transcendent, and eternal - has had tremendous power. It is the power that we call inspirational when produced by those we follow or admire. It is about knowledge that is understood as based on objectivity and which claims that it is able to overcome the prejudices of an individual or community. A text from the past or its meaning is seen as something that is fixed and un-interpreted. Objectivity seeks to find knowledge without any distortion. It operates on the principle of neutrality and detachment, distancing itself from values in interpretation. In doing so, it consults models (a methodology?) for the best knowledge possible, while at the same time denying the possibility that knowledge could not fail to 'bear the mark of its producers, or the processes of its production' (Code 1994:181). It is an attitude based on "impartiality" that [holds] the passions, if not the personal at bay' (Daston 1994:38). This objectivity aims to establish a kind of knowledge that could be possessed without taking into account any particular historical, cultural or circumstantial conditions and that is free from the perspectives of particular interpreters. In doing so it 'pays no heed to the diverse experiences and circumstances that often produce an imperfect fit between principles and situations' (Code 1994:182). Objective thinking starts with the notion of the passivity of the observer, which is made possible through its methodology, with its objective standards leading to criteria of certainty. Objective thinking, in its methodology, forgets its own historical situated-ness.

Objective thinking, then, is an attempt to find 'one truth' against all the possibilities for truth. Texts are seen as objects as they exist independent of 'the inquirer's thoughts and desires regarding them' (Hawkesworth 1994:151). It thus promises that there is something like a rational method of interpretation, which 'can be utilized regardless of social context or the phenomenon being investigated' (Hawkesworth 1994:152). However, can objective thinking, with its insistence on methodology as starting point, lead us to truth in biblical interpretation? Or is the location of truth to be found elsewhere?

\section{Biblical interpretation and the liberation of prejudices}

The current understanding of hermeneutics includes the question, 'Can hermeneutic theory do justice both to the recognition of the historicity of interpretation and to the experience of truth in understanding?' (Selby 2006:136). The liberation of prejudices as the link between past text and current interpreter or the hermeneutical notion of the fusion of two horizons endeavours to answer this question. The main task of hermeneutics is to justify and establish the implications of the fusion of two horizons - that is, that interpretation or the use of the Bible takes place within horizons of already-granted meanings and intentions, also known as prejudices. How can one, therefore, describe the hermeneutical experience - that which happens in all understanding, or the experience of truth in understanding, and the historicity of interpretation? 


\section{Belonging to the world}

Understanding is an event rather than a method. The basis of understanding is that we belong to the world more than the world belongs to us. More than our critical judgements, prejudices constitute the foundations of the way we belong to the world. Understanding is thus a fundamental characteristic of our existence and prejudices constitute our understanding. If truth cannot be verified with method (espousing a methodology) then truth is to be found in the experience of the world (an ontological bias).

In his hermeneutical-philosophical work, Hans-Georg Gadamer, more than anyone else, has made us aware of the positive role of prejudices in understanding by claiming that this hermeneutical experience is 'truth that does not only, and perhaps not even primarily rely on what has an absolutely firm foundation, as scientific methodology insist [s] ...[It] is to value experiences of truth, of "knowledge", which go beyond the infinitely restricting limits of what allows it to be objectified in a method of knowledge' (Grondin 2003:22). In holding to method or methodologies as that which makes for truth in relating past text to current interpreter, we are busy with 'extricating them (witnesses of past time) from the preoccupations of our own present life' (Bleicher 1980:130). We are always discovering that we are already within a specific historical context and that we have a past. Because of this way we belong to the world, we always understand something already, and therefore any understanding begins with our fore-structures of meaning. This means that the 'inherited tradition forms the initial point of departure for all acts of understanding' (Schmidt 2006:100). Because of our historical finitude there is a pre-given-ness into which we are born. Our reflections are thus already informed by our historical situated-ness.

\section{Primacy of the game}

Gadamer uses the metaphor of a game being played. What is important is the primacy of the game, the historical consciousness is favoured over the consciousness of the individual players. The game is the master of the players as the players react to the rules and task imposed on them by the game. In terms of what is presented to the audience, the player is only an element of the whole. The performance exists in the interaction with the audience. In this performance, a world that is presupposed and created emerges, as in a work of art. To take this further, each performance is different, for any game that seeks to merely reproduce itself as an exact copy of a previous game will not be a game anymore. Gadamer uses the concept of effective history to show the dominance of the game over players. Before we understand ourselves through self-reflection, we understand ourselves in what is a self-evident way and it is in this that truth cannot be an individual-centred rational reflection but is rather based on context-related foundations. The ethical implication of this is that there can be no preset rules for a correct interpretation, for each game is different in its performance as it is actualised on the horizon of the current audience. Take also, for instance, the interpretation of a work of art. What comes to the fore, more than a merely aesthetic experience, is an experience of the truth-claim of the work and to this experience we bring our own world. This provides for a hermeneutical experience as a productive exercise rather than a mere reconstruction of the past-ness of the work of art.

\section{Language and anticipation of meaning}

We can also point to language to highlight the fact that all understanding necessarily (ontologically) proceeds from anticipation of meaning. In understanding something we have translated it into our own language. If we always translate something into our own language it means that different interpreters in different historical times would have different expanded horizons. The correctness of a text, therefore, would be stated differently in different contexts. "There cannot, therefore, be any single interpretation that is correct "in itself"'(Schmidt
2006:118). This is how interpretation 'works', for every language is a particular view of the world and there is no 'perfect' language. Thus we can say that all interpretation is speculative, as each 'performance' of the text is different, even though the subject matter is the same. To understand is to let a subjectmatter address us - in this way it is an event in which something meaningful happens to us. We can also say that interpretation or understanding is like a conversation or dialogue in which the questions we put to the text always presuppose something in order to bring what is being questioned out into the open. The text (as historical text) poses a question to the interpreter because it affects the interpreter. To answer the question posed by the text, we will have to ask the question, to which the text is the answer. But the interpreter goes beyond the "historical horizon of the question to which the text was an answer since she cannot ignore what she knows and the author did not know' (Schmidt 2006:113).

\section{Tradition and application}

The distance between ancient text and today should not be ignored since it makes understanding possible. The tradition in which we stand is always the interpretation of that tradition within concrete situations. It has its validity only in its applications. The texts only exist in their application, but this application is done not as an after-thought but as that which is already happening as we 'move' toward the text from within the way we belong to the world. There is always a movement toward the object, which is already part of the interpreter. In other words, following Gadamer, we understand differently, if we understand at all. We are thus moving from hermeneutics as based solely on methodologically justified knowledge and thus objective readings - as for instance in uncovering the author's or final redactor's intent, which is valid for all times and under all circumstances - toward an understanding which is 'integration', where we cannot separate subject from object. Therefore, there is a need for an ontological bias without neglecting methodology in interpretation. Without methodology, we cannot complete the task; however, the locus for truth in biblical interpretation is found elsewhere and it is this that makes methodology possible in the first place.

\section{Practical wisdom}

To further underline the ethical implications of Gadamer's work we can turn to the concept of practical wisdom or phroneses. Truth, Gadamer claimed, is rather found in that which is based on belief, integrity and probability, in which ultimate foundation is lacking. Furthermore, he claimed that truth is found in practical wisdom, that which '... always what concerns me directly, without it being a matter of technique' (Grondin 2003:22). Practical wisdom can be seen as prudence, reasonableness and discernment. It is not an ability in the sense of technique but rather a way of being, for instance in being reasonable. Practical knowledge is thus different from theoretical and technical knowledge. We are always already acting and thus ready to apply our moral knowledge. It is not something we possess beforehand and apply when the situation arises; rather, moral knowledge is something we discover we have as we go along and is not independent of the situation.

It is more like applying the law than applying the skills we have learned in a craft. The judge applies the law or rule with a view to the specific case under consideration. 'Moral application, then, is always more than technically subordinating a case to its appropriate rule in an automatic fashion; moral applications, as illustrated by legal judgment, requires a discerning wisdom about the various "rules," written and unwritten, which are appropriate to the particular case' (Foster 1991:63).

As referred to earlier, the following question arises: 'which prejudices are legitimate and which are not?' It is the contention of this article that for prejudices to be legitimate - that is, to lead to responsible use of the Bible in Christian ethical decision- 
making - they must be conformable to an ethics of responsibility and the corresponding value orientations as a fundamental starting point in ethical decision-making.

\section{WAYS IN WHICH RESPONSIBILITY SHOULD QUALIFY CHRISTIAN ETHICS}

In his article, 'Prospects of a Christian ethics of responsibility (Part 2): An assessment of three German versions', D.E. de Villiers (2007) provides a summary, yet not a final say, on how responsibility as a meta-ethic can qualify Christian ethical decision-making. He proposes five ways in which responsibility should qualify Christian ethics today:

Christians should not regard their moral obligations as narrow and very specific moral commands or duties that they have to fulfil in obedience to God, but rather as broad and comprehensive moral responsibilities that they have to assume and to give account of to themselves, fellow human beings and God. They have the responsibility to contribute to the constitution of moral obligations in our time, which entails the responsibility to formulate new moral directives where necessary, find the moral consensus needed in particular situations of moral decision making, as well as the responsibility to conclude agreements or covenants among those involved to commit themselves to act in accordance with the moral consensus, where such a commitment is lacking. They have the responsibility to do justice to both moral obligations and the functional obligations that are prevalent in the different social systems without forfeiting the priority of moral obligations. They also have the responsibility in the present situation, earmarked by moral plurality, to take into account the consequences of the available options for action, especially their effect on the freedom of conscience of people who do not share their moral convictions. The responsibility to take the consequences of available options for action into account also relates to the consequences such action would have for the preservation of the environment and for the survival and quality of life of future generations.

(De Villiers 2007a:106)

We can see here that responsibility is not turned into an imperative or conceived as an exclusive future-ethics, nor is there an attempt 'to find a universally recognised foundation for it' (De Villiers 2007a:89). In his article, De Villiers refers to the contributions of Wolfgang Huber, Johannes Fischer and Ulrich Körtner. According to Fisher, what is new in ethics today is that it is not our task so much to discover our moral responsibility as much as it is to create moral responsibility with others. This means that rather than to 'ground moral responsibility objectively in human nature or the nature of the world it should rather endorse the search for that which we should make each other responsible for and contribute constructively to the societal process of restoring moral responsibility' (De Villiers 2007a:95). Körtner states that we are, in the first instance, responsible to God. An ethics of conviction sees ethical decision-making in terms of the moral agent's duty and autonomous acts. An ethics of responsibility, however, characterises the moral situation in a forensic sense. This means that the following questions become all important: '[w] ho is the responsible agent, who (or what) is the instance holding the agent responsible, and what is the sphere in which the agent is held responsible?' (De Villiers 2007a:96). The concept of responsibility has thus effected a fundamental change in the understanding of morality. This change can be described as a move from the moral agent having to obey specific duties as set out or promulgated by a lawmaker, as for instance in (1) receiving God's command, (2) obeying God's command, (3) giving account to God of obedience or the lack of obedience, toward giving account of one's actions and their consequences to an instance which holds one accountable. We can thus say that the fundamental moral situation entails more than just giving account before God or another instance of what one has done in the past. The fundamental moral situation consists also of the constitution of the relevant moral directive(s), the personal assumption of the moral directive(s) as one's own obligation and the application of this (these) moral directive(s) in real-life situations' (De Villiers 2007a:105).

\section{FROM WAYS TO PREJUDICES}

Based on Weber's original distinction between an ethics of conviction and an ethics of responsibility, we can say that the moral agent uses either the one or the other as departure point. But understanding for moral action is a fundamental human characteristic. One can thus refer to the moral agent as a moral character or personality. In other words, one's moral action is an outcome of one's moral character or personality and as such influences one's point of departure and corresponding value positions in one's ethical decision-making. Also, one's moral character or personality has to do with the way one belongs to the world and thus one's prejudices or pre-understandings.

Weber speaks about personality:

[i]n an ethical sense, defining it in terms of the consistency of its inner relationship to certain ultimate values and meanings of life, which are turned into purposes and thus into teleologically rational action

(Weber 1979:73)

He also 'comprehends personality as the consequence of a behavioural deification, which results from the character of the value system and manner in which persons are socialised' (Weber 1979:73). There is thus an affinity between one's character and one's value orientation that has to do with one's moral context and thus with one's ethical or moral action.

A way of belonging to the world is to be responsible as a result of the value system and manner in which one is socialised. To speak about belonging to the world is to speak about prejudices constituting the way one belongs to the world. These prejudices will lead to the responsible use of the Bible today only if they are conformable to the ways in which responsibility should qualify Christian ethics in general.

The following three ways constitute the moral agent's prejudices as he or she approaches the use of the Bible in ethical decisionmaking:

1. What is aimed for is accountability to God, others and self, in terms of broad moral responsibilities. There should thus be a movement from obedience to responsibility.

2. The dialogical nature of ethical decision-making between different value systems or spheres should be taken into account in order to accommodate them all optimally. There is a movement toward the constitution of moral norms of our day in solidarity with others in a context characterised by plurality in and conflict between different value spheres.

3. Ethical decision-making is relational and it takes into account the reality of the world in which it happens as well as the consequences of one's moral actions.

Within a plurality of approaches and methods available to modern interpreters, only the approaches to the use of the Bible and exegetical methods that will allow themselves to be influenced by these prejudices as their pre-understanding for moral action can lead to responsible acts of interpretation.

\section{UNDERSTANDING AND TEXTS}

Drawing from what has been said thus far, biblical interpretation therefore consists of three basic elements. The first is to provide some kind of overview of what the text points to. The second is to gain a deeper insight into the subject-matter of the text. For this, some element in the retrieval of authorial intent is necessary, but it goes further than that, for there is a truth claim by the text in respect of the subject-matter. The interpreter already has some fore-knowledge of the subject matter and can only view the subject matter from the standpoint of what he or she already knows about the subject matter. In this sense, 
the current interpreter knows more than the author and the questions asked of the text; answers given will be based on this 'more'. This 'more' includes the prejudices that constitute the way the interpreter 'belongs to the world' and also by means of which the interpreter does his or her interpretative work. It has to do with that which the interpreter accepts as 'true' in relation to a specific subject-matter and in relation to what constitutes for him or her the fundamental starting points in his or her moral action. A third element is to return to the first element, the historical work, with this new insight into the subject-matter and thus with a critical view on the work done in the first element. This means that in biblical interpretation, there is 'the to-and-fro type of process which allows one's first ideas to be shattered and corrected by the text, leading to ever new readings' (Selby 2006:153).

Already in choosing one approach or reading over another, one engages in a moral act, which means that one's prejudices are already at work. If one's prejudices are conformable to the ways in which responsibility should qualify Christian ethics, one's reading must include the ability to have dialogue between different value systems, thus taking into account the relational nature of ethical decision-making, the reality of the world and the moral agent being critical toward the consequences of such a reading on the text and on others. It must bring to the reading the 'more' the current interpreter knows about the subjectmatter and the understanding of ethics to be responsible if it wants to be adequate. Methodology has an instrumental function in biblical interpretation once the location for truth in biblical interpretation has been located in the hermeneutical experience of prejudices as that which make all understanding possible (the ontological bias). As such we cannot complete the task without our methodologies; the location for truth, however, is found somewhere else.

\section{A brief example: Romans 1:26-27 and same-sex civil unions}

Romans 1:26-27, based on a social-scientific reading, points us to the following: they (that is, societies who have exchanged worship of God for idolatry, or Creator for creatures, are given over, tit-for-tat, to sexual behaviour that transgresses genderand honour-based social expectations and roles. The boundaries of these gender-based and honour-based expectations and roles have their origin in monotheism and creational intent as first expressed in Israelite social, cultural and religious customs and conventions. This served to maintain her exclusivity as a nation. That is why same-sex relations are against what is natural and thus punishable by death. Those who engage in such behaviour are given over to the wrath of God because they do not fit what is socially natural or customary. This was typical of those societies who did not honour the one and only God (Malina 2002a:141-150; 2002b:393-407).

We can ask whether, in terms of current-day understandings of human sexuality and what constitutes that which is customary and valid in different value systems, this text could be used to condemn same-sex behaviour in all circumstances. Can we, using this text, condemn current-day same-sex civil unions? ${ }^{3}$ The politician is responsible for upholding the Constitution, which entails non-discrimination with regard to sexuality. We are thus also dealing with functional values. This is part of the current-day context in which ethical decision-making happens, which forms part of the 'more' we know. We also know 'more' (different) about gender-based roles and expectations.

The author's intent is broadened to include categories of behaviour that we are dealing with today. By dealing with the text from within current-day categories/horizons we have

3.At present, the Constitution of South Africa does allow for same-sex unions (Act 17 of 2006). The couple can choose whether (under this act) to have their union recognised as a civil union or as a marriage with the same privileges and responsibilities as under the Marriage Act of 1961. (See http://en.wikipedia.org/wiki/ Same-sex_marriage_in_South_Africa). already applied the text to/for our current-day situation. In addition, we have not moved outside the truth-claim of the text for the questions asked of the text and answers given were based on the 'more' we know, in relation to the subject-matter. For instance, in dealing with the text we have taken note of the difference between the cultural notion of moral behaviour embedded in one's social network dominant in biblical times, as opposed to the current understanding of behaviour as a consequence of or embedded in one's individuality. Not taking note of this difference in the meaning of the text would be to deny the current-day categories from which we read the Bible. That is, the interpreter is denying the currentday pre-understanding of moral behaviour embedded in individualism, thereby reading the text as if moral behaviour today is embedded in the same categories we find in biblical times. It is precisely this (historical) difference that brings out the meaning of the text for us today - that is, that we cannot use this text to condemn homosexual behaviour in all circumstances, for we are today dealing with social behaviour embedded in individualism. The meaning of the text must deal with the reality of the world today. It does not mean that the text has nothing to say to us about same-sex behaviour but what it has to say must adhere to the truth-claim of the text. There was also a movement from what was customary for Israel, in terms of the expected norms of the day, to be applied in a 'principled and obedient way' to the broader moral responsibility we have today toward the constitution of moral norms with others of our own time.

\section{CONCLUSION}

If prejudices [pre-understanding] are that which make all understanding - including understanding for moral action possible, then the interpreter, in her or his use of the Bible as a source for moral norms in the process of her or his ethical decision-making, is confronted with the following question: what are the criteria for determining what is justifiable in one's prejudices and what is not? There thus needs to be an intentional and critical engagement with her or his prejudices so as to give an answer to her or his reflection 'on the ethics of interpretation [so as] to reflect on what kinds of acts of interpretation are responsible in a number of senses' (Botha 1994:42). The ethical work in one's interpretation - this reflection [the ethics of biblical interpretation] - cannot be separated from the work of engaging with an ethical issue confronting the interpreter as moral agent (Christian ethical decision-making). This affinity can exist in terms of the liberation of prejudices as that which makes all understanding possible.

In order to use the Bible responsibly in Christian ethical decision-making, one's prejudices must be conformable to the ways in which responsibility should qualify Christian ethics in general. The opposite of responsibility in Christian ethical decision-making, and therefore that which should be resisted, is the ethics of conviction that causes historical objectivism in the interpreter as moral agent, which in turn cannot lead to responsible use of the Bible in Christian ethical decisionmaking, as it denies the positive role of prejudices in its ethical decision-making. The ethics of conviction do not engage critically and intentionally with prejudices as that which makes all understanding possible. It denies that all understanding proceeds (ontologically) from one's pre-understanding or prejudices and thus assigns a negative role to prejudices. This cannot lead the interpreter to adhere to the truth claim of the text. The truth claim of a text is always a productive exercise; it is the fusion of two horizons, in which one's prejudices come face to face with those of the text, rather than being a mere recreation of the past-ness of the text.

However, further investigations are necessary to determine which prejudices are legitimate and which are not in the ethics of biblical interpretation, with specific reference to the use of the Bible (the hermeneutical work) in Christian ethical decision-making related to specific ethical issues confronting 
the Christian interpreter as moral agent. These investigations need to be done according to the model of Christian ethical decision-making developed by H.E. Tödt. According to Tödt, an investigation into

'the real context' in which the problem arises (for instance, the social and political framework, the relationships to personal or group life and action) [is necessary], in order to determine how the definition and solution of the respective problem is conditioned by the context.

(Tödt 1996:292)

This model of ethical decision-making allows for the use of the Bible as a source for moral norms in the process of ethical decision-making itself. Within such a model it is thus possible to investigate the prejudices underlying the various approaches to the use of the Bible and exegetical methods available to the modern interpreter in terms of the ways that responsibility should qualify Christian ethics in general, so as to ascertain which prejudices are legitimate and which are not, ultimately leading to clearer guidelines for the responsible use of the Bible.

\section{REFERENCES}

Bleicher, J., 1980, Contemporary hermeneutics: Hermeneutics as method, philosophy and critique, Routledge \& Kegan Paul, London.

Botha, J., 1994, 'The Bible and ethics', in C. Villa-Vicencio \& J. de Gruchy (eds.), Theology and praxis, doing ethics in context, South African perspectives, vol. 2, pp. 36-45, David Philip, Cape Town.

Code, L., 1994, 'Who cares? The poverty of objectivism for a moral epistemology', in A. Megill (ed.), Rethinking objectivity, pp. 179-196, Duke University Press, Durham.

Daston, L., 1994, 'Baconian facts, academic civility and the prehistory of objectivity', in A. Megill (ed.), Rethinking objectivity, pp. 37-64, Duke University Press, Durham.

De Villiers, D.E., 2005, 'The vocation of reformed ethicists in the present South African society', Scriptura (89), 521-535.

De Villiers, D.E., 2007a, 'Prospects of a Christian ethics of responsibility (part 2): An assessment of three German versions', Verbum et Ecclesia 28(1), 88-109.
De Villiers, G., 2007b, 'Die huwelik as "instelling van God" (met implikasies vir gay huwelike) [Marriage as instituted by God (with implication for gay marriages)]', Verbum et Ecclesia 28(1), 110-126.

Foster, M., 1991, 'Hermeneutics and practical philosophy', in L. Cunningham (ed.), The hermeneutics of moral confidence, pp. 45-75, American Academy of Religion: Studies of Religion, Scholars Press, Atlanta.

Grondin, J., 2003, The philosophy of Gadamer, Acumen, Durham.

Hawkesworth, M., 1994, 'From objectivity to objectification: Feminist objections', in A. Megill (ed.), Rethinking objectivity, pp. 151-178, Duke University Press, Durham.

Malina, B., 2002a, 'The New Testament and Homosexuality? Part1: The Social System behind Romans', Verbum et Ecclesia 23(2), 141-150.

Malina, B., 2002b, 'The New Testament and Homosexuality? Part2: The traditions Influencing Paul's thinking in Romans' 1, Verbum et Ecclesia 23(2), 393-407.

Montgomery, J., 1995, 'Legal hermeneutics and the interpretation of Scripture', in M. Bauman \& D. Hall (eds.), Evangelical hermeneutics, pp. 15-30, Christian Publications, Camp Hill.

Schmidt, L., 2006, Understanding hermeneutics, Acumen, Stocksfield.

Selby, R., 2006, The comical doctrine: An epistemology of New Testament hermeneutics, Paternoster, Exeter.

Smith, B., 1994, 'The unquiet judge: Activism without objectivism in law and politics', in A. Megill (ed.), Rethinking objectivity, pp. 289-311, Duke University Press, Durham.

Thiselton, A., 1980, The two horizons: New Testament hermeneutics and philosophical description with special reference to Heidegger, Bultmann, Gadamer and Wittgenstein, Paternoster, Exeter.

Tödt, H.E., 1996, 'Towards a theory of making ethical judgments', in D. Clark \& R. Rakestraw (eds.), Readings in Christian ethics, theory and method, pp. 279-283, Baker Books, Grand Rapids.

Weber, M., 1979, 'Value-neutrality and the ethics of responsibility', in G. Roth \& W. Schlucher (eds.), Max Weber's vision of history, ethics and methods, pp. 65-116, University of California Press, Berkeley. 